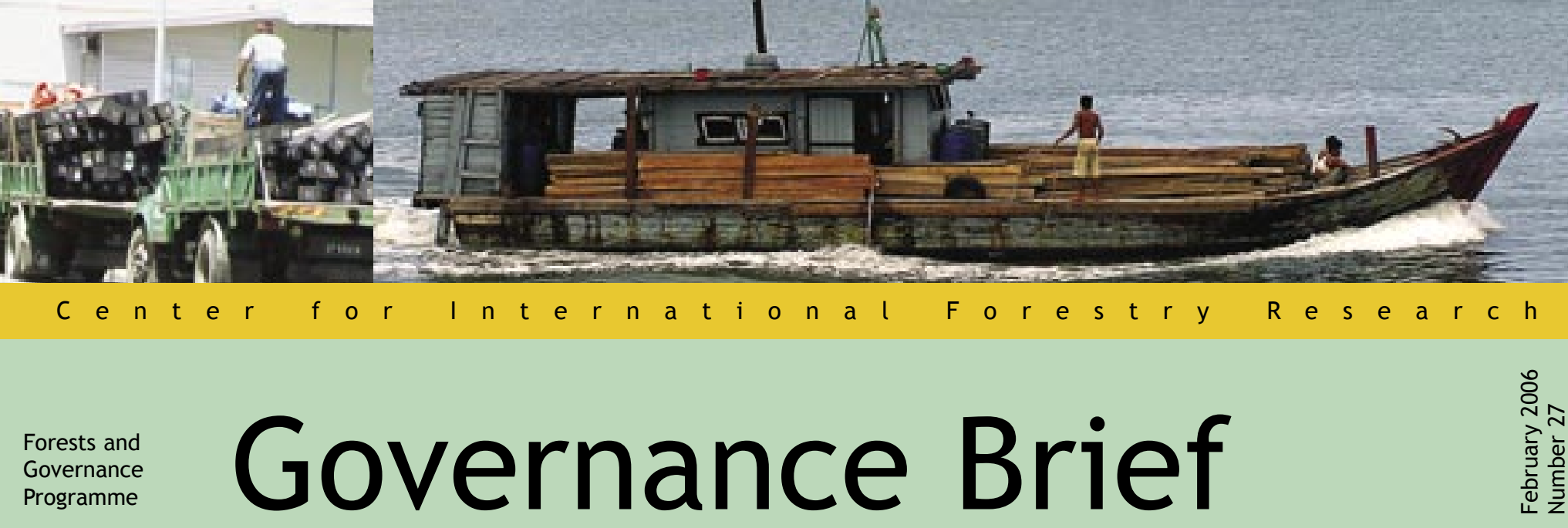

\title{
The cross border timber trade in Kalimantan: Will stopping timber smugglers help solve the illegal logging problem in Indonesia?
}

\author{
Krystof Obidzinski, Agus Andrianto, Chandra Wijaya, \\ Dody Hernawan and Christoforus W. Belle
}

\section{Background}

Indonesian forestry officials, timber industry associations, NGOs and research institutions are of the opinion that timber smuggling is a key contributor to the illegal logging problem in Indonesia. It is often stated that international crime syndicates, run mainly from the neighboring countries (i.e. Malaysia), are responsible for timber smuggling activities. Other assumptions are that if Malaysia and Indonesia cooperated, smuggling could be eliminated, and if timber smuggling was stopped, the illegal logging problem in Indonesia would be under control.

These are sweeping assumptions that so far have not been systematically analyzed. This study was aimed to look more comprehensively at the dynamics, extent, nature and modus operandi of timber smuggling between Indonesia and Malaysia in Kalimantan and to assess the claims that are being made about the significance of timber smuggling within the context of the illegal logging problem in Indonesia. The results of this study will be used to inform the on-going debates on this issue and contribute to possible corrective measures.

\section{Objectives}

The main objective of this study is to carry out a comprehensive assessment of timber smuggling activities from Indonesian Kalimantan to Malaysia (Sarawak, Sabah), in order to evaluate the contribution of timber smuggling to the illegal logging problem in Indonesia. The assessment was designed to understand the dynamics, extent, location, major actors, volumes and values, and modus operandi of such activities.

The study's other two objectives are to:

- Identify the weaknesses in current efforts to control the cross-border timber traffic and prepare possible solutions for presentation to Indonesian and Malaysian governmental institutions.

- Inform the on-going debates among Indonesian and Malaysian government institutions, NGOs and research organizations about the contribution of cross-border timber smuggling to the illegal logging problem in Indonesia.

\section{Methods}

The study of timber trade activities in the Indonesia-Malaysia border zone in Kalimantan was structured around the following methodological steps:

- Review and synthesis of the available, published and unpublished, sources on cross-border timber trade, plantation establishment, infrastructure development etc

- Analysis of available timber trade documentation

- Analysis of the remote sensing imagery for possible timber traffic points along the border

- Aerial survey of the borderline to establish which cross border routes are in still in use

- Ground investigation of a sample of timber traffic points along the border 


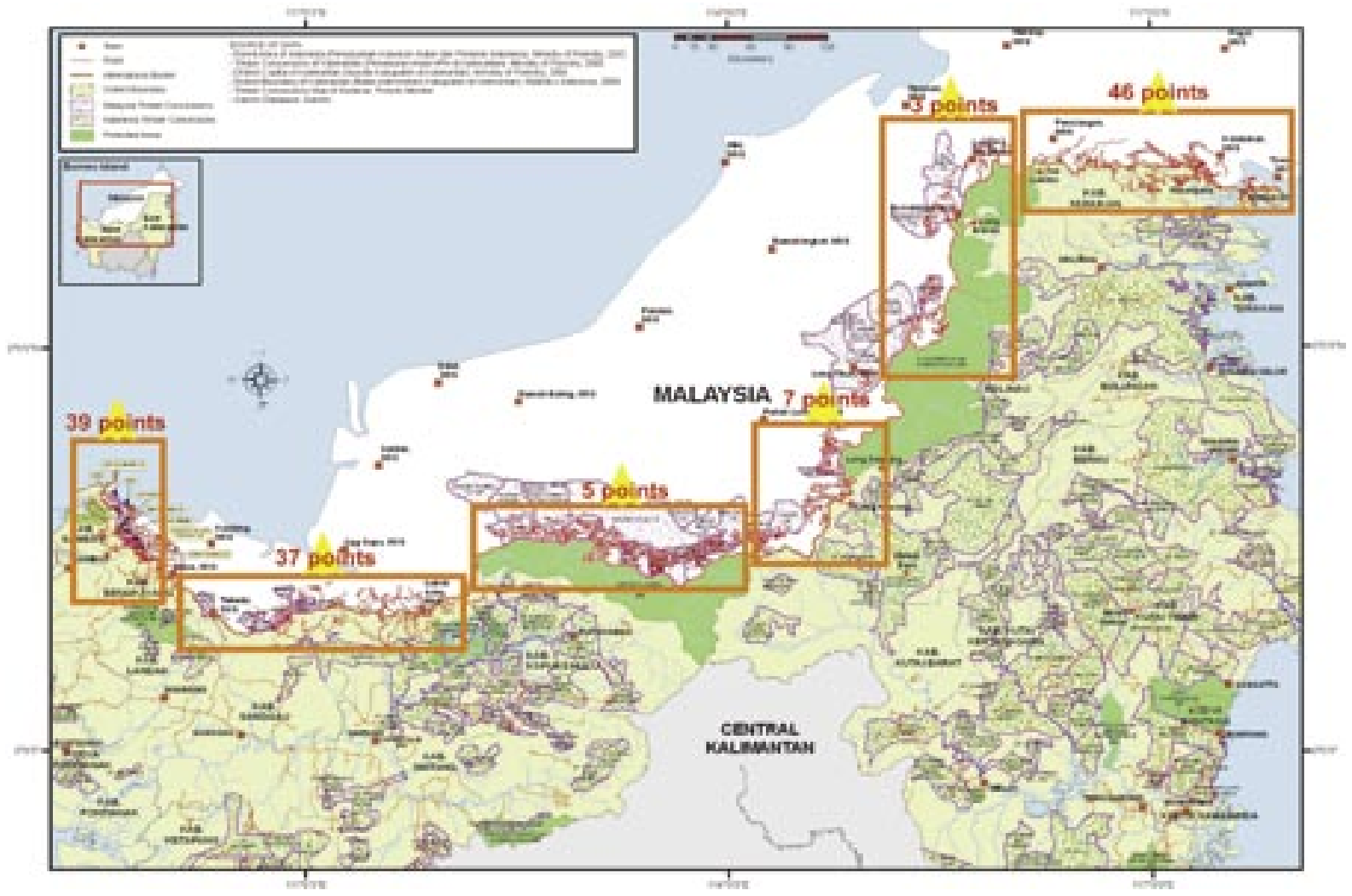

\section{Key findings}

\subsection{The magnitude of legal and illegal timber trade}

The latest official figures indicate in 2003 the export of wood products from Indonesia to Malaysia was $832,319 \mathrm{m3}$ - about half of it originating from Kalimantan. At the same time, the volume of timber traded illegally that year from Kalimantan to Malaysia was estimated at between 2 and 4 million $\mathrm{m} 3$.

The official timber trade figures for 2005 are not yet available, although they are estimated to be roughly in the same range as in 2003 or showing a slight decline. The illegal timber trade, on the other hand, dropped significantly.

In 2005, there were 6 official entry points for timber trade along the Indonesian-Malaysian border in Kalimantan - 5 in West Kalimantan and 1 in East Kalimantan. However, in reality intermittent or regular timber traffic was taking place in 137 border points (81 points in West Kalimantan and 56 points in East Kalimantan). The volume illegally traded in 2005 is estimated at around 1 million $\mathrm{m} 3$.

\subsection{Incentives against legal and for illegal timber trade}

The level of timber traded illegally from Indonesia's Kalimantan to Malaysia has fallen significantly over the last 1-2 years - mainly due to a stronger commitment on the part of the Indonesian government to surveillance and law enforcement. Still, there are aspects of timber trade beyond law enforcement that need to be addressed if the level of illegal timber trade from Indonesia to Malaysia (and elsewhere) is to be reduced further.

\section{Incentives against legal and for illegal timber trade in Indonesia}

- Export permits controlled by government bodies such as ETPIK (Registering Body for the Exporters of Timber Products) and BRIK (Body for Revitalization of Forest Industries), heirs to the infamous monopoly of APKINDO

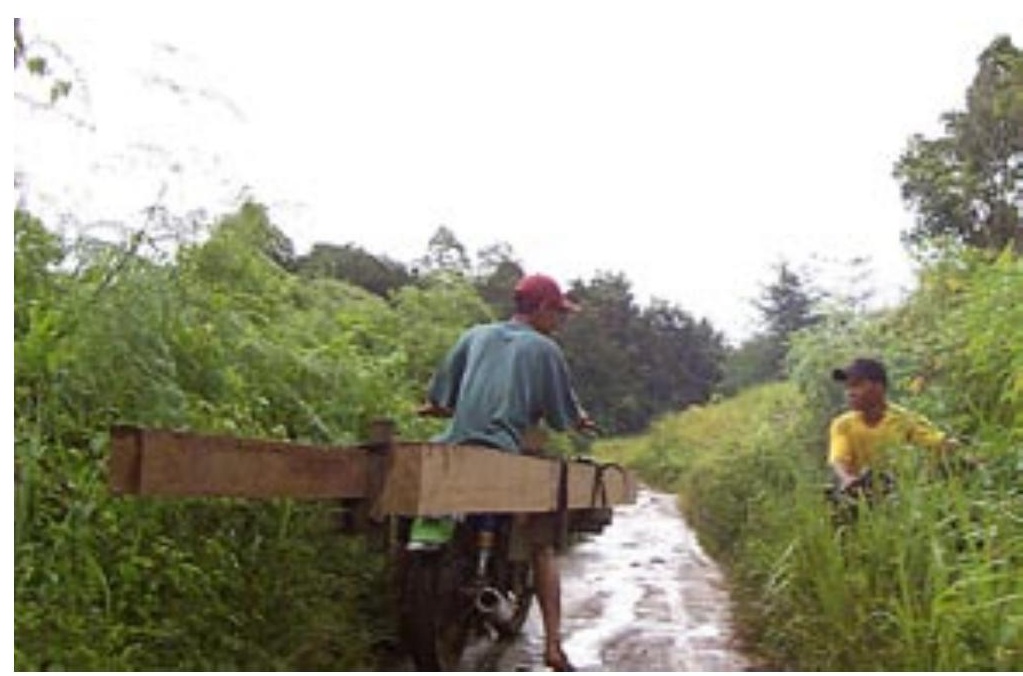




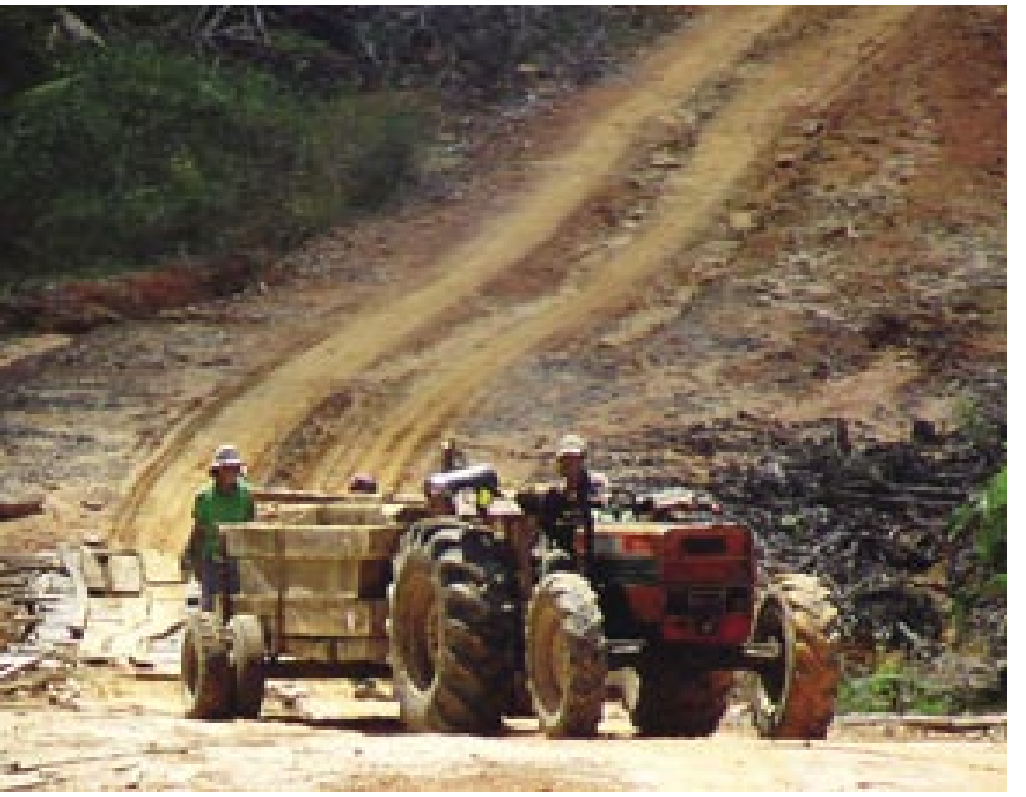

(Association of Plywood Producers in Indonesia)

- Bureaucratic red tape: there are at least 13 distinct steps to follow and a mass of documentation to sort out for timber export of any size to proceed

- Complexity, high transaction costs, process/ system oriented towards large, established companies

- Small and medium operators unlikely and/or unwilling to adhere to it

- Inter-institutional collaboration (forestry, police, customs, navy etc) for surveillance and law enforcement improving, but still a work in progress

- Bilateral Indonesian-Malaysian collaboration on the ground (forestry, police, customs, navy etc) haphazard; the targeted close collaboration unrealized

- Limited capacity to monitor the border zone regularly beyond the areas readily accessible by road or water transportation - short distances from the point of origin to the destination and many "alternative" routes

- Anti-graft campaign intensifying, but (if sustained) will be a very lengthy process

Factors supporting the Malaysian import of illegal timber from Indonesia

- Overriding mandate/objective of border controls (especially Customs) to encourage trade

- High demand for the low-cost raw material for the woodworking sector - Indonesia an obvious choice

- FTZ (Free Trade Zone) regulations effective along the Sarawak-Kalimantan border: minimal documentation required for imported timber
- BTZ (Barter Trade Zone) regulations effective in the port of Tawau: minimal documentation required for imported timber

- Much of timber smuggling from Indonesia is financed by Malaysian traders who possess legitimate import licenses

- Limited understanding of and capacity to verify trade documents originating from the Indonesian side of the border

- Bilateral Malaysian-Indonesian collaboration on the ground (forestry, police, customs, navy etc) limited; the targeted close collaboration unrealized

- Limited capacity to monitor the border zone regularly beyond the areas readily accessible by road or water transportation. Most active FMUs (logging concessions) in Malaysia operate within kilometers (in some cases only hundreds of meters) of the border line with Indonesia. As logging roads rarely link up with the public road network, the real time monitoring of these remote sites is difficult

Necessary steps toward further reduction of timber smuggling from Indonesia to Malaysia:

\section{Measures in Indonesia}

- Streamline timber export licensing procedures

- Eliminate/reduce bureaucratic red tape

- Reduce costs and complexity to encourage small and medium timber exporters

- Continued emphasis on inter-institutional collaboration (forestry, police, customs, navy etc) for surveillance and forest law enforcement

- Continued emphasis on bilateral IndonesianMalaysian collaboration (forestry, police, customs, navy etc)

- Continued emphasis on fighting corruption in Indonesia's forestry sector and elsewhere

- Emphasis on building capacity to monitor the border zone regularly

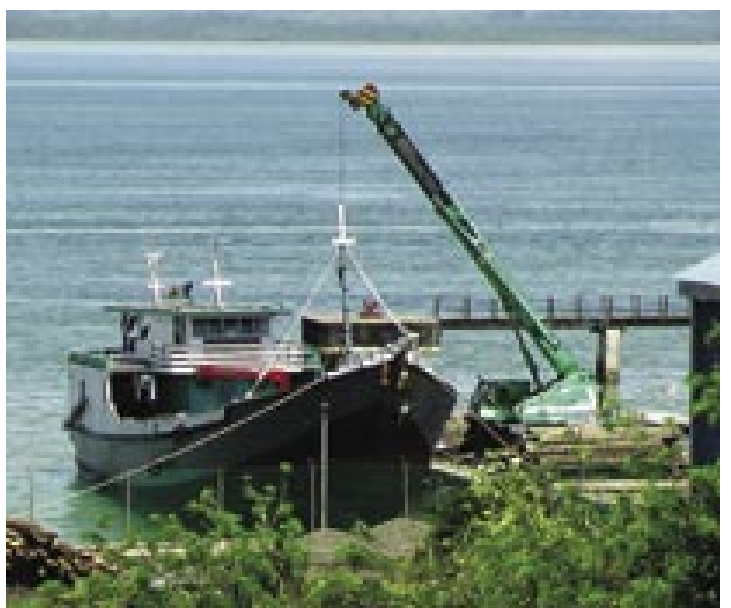




\section{Measures in Malaysia}

- Closer supervision of FTZ (Free Trade Zone) along the Sarawak-Kalimantan border: stricter documentation requirements for timber imported from Indonesia

- Closer supervision of BTZ (Barter Trade Zone) in the port of Tawau in Sabah: stricter documentation requirements for timber imported from Indonesia

- Closer collaboration with the Indonesian side to verify Indonesian timber trade documents (customs)

- Bilateral Malaysian-Indonesian border zone collaboration sustained (forestry, police, customs, navy etc)

- Building capacity to monitor the border zone regularly

\subsection{The significance of timber smuggling within the context of illegal logging in Indonesia}

Despite recent successes of the Indonesian and Malaysian governments in curbing illegal cross border timber trade, well-entrenched structures of disincentives for legal timber trade between Indonesia and Malaysia are likely to sustain a certain level of timber smuggling between both countries. The question arises whether it is worth the time, effort, resources and social discontent to try to dent timber smuggling in the border zone further, or to look at it within the overall context of illegal logging and illegal timber trade activities in Indonesia and take stock.

It is well known there are large discrepancies between the volume of timber products officially exported from Indonesia and the volume reported as the official import in destination countries. For instance, for sawn timber alone Chinese trade statistics show that Indonesian

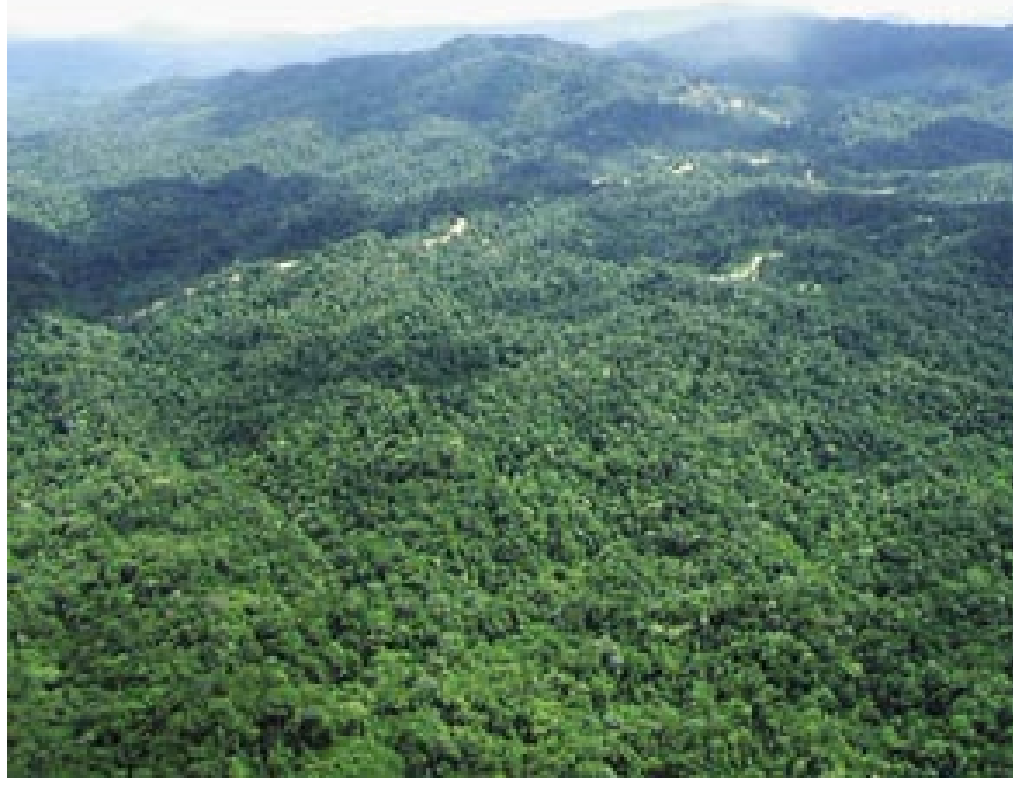

timber export to China is over 1.5 million $\mathrm{m} 3$ more than what Indonesia records as its export to China. Similar discrepancies affect other timber products (plywood, woodchips, furniture etc) and such differences can also be observed in the statistics of other timber importers from Indonesia (Japan, Korea, Taiwan, Vietnam etc). Overall, trade discrepancies of this kind run into millions of cubic meters of processed timber products per annum.

It is clear that most of illegal timber trade is done not clandestinely in remote border crossings, but through regulated timber trade channels by means of manipulation of documents for the purposes of underreporting of the actual timber volumes being traded. The illegal logging that feeds Indonesian domestic timber industries that subsequently understate their export figures is the crux of the problem. While politically expedient, the focus on cross border timber smuggling is unlikely to contribute significantly to the reduction of illegal logging and illegal timber trade problems in Indonesia.

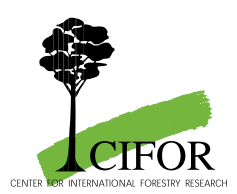

Center for International Forestry Research, CIFOR Office: Jalan CIFOR, Situ Gede, Sindang Barang, Bogor Barat 16680, Indonesia.

Mailing: P.O. Box. 6596 JKPWB, Jakarta 10065, Indonesia
Tel: +62(251) 622622 Fax: +62(251) 622100

E-mail: cifor@cgiar.org Website: www.cifor.cgiar.org Front page photos: Petrus Gunarso and Carol J.P. Colfer 